\title{
LADISLAVELLA OCCULTA (JACKIEWICZ, 1959) - A SPECIES OF AQUATIC SNAILS NEW FOR HUNGARY WITH REMARKS ON ITS DISTRIBUTION IN CENTRAL AND EASTERN EUROPE
}

\begin{abstract}
MAXIM V. VinARSKI
Laboratory of Macroecology \& Biogeography of Invertebrates, Saint-Petersburg State University Russian Federation; E-mail: radix.vinarski@gmail.com, https://orcid.org/0000-0002-7644-4164

A finding of the lymnaeid species Ladislavella occulta (Jackiewicz, 1959) [Mollusca: Gastropoda: Lymnaeidae] in Hungary is reported, which is the first record of this aquatic snail in the country. The shells of L. occulta were found in 1989 in the marsh area of the Bátorliget Nature Reserve. The current distribution of this species in Eastern and Central Europe is reviewed. It is hypothesized that L. occulta represents a relic species, whose origin may be traced back to the Pleistocene.
\end{abstract}

Key words: Ladislavella occulta, Lymnaeidae, aquatic snail, Hungary, fauna, Bátorliget Nature Reserve, Pleistocene relic.

\section{INTRODUCTION}

The freshwater malacofauna of Hungary has been extensively studied since the middle of the 19th century. A series of comprehensive works of Hungarian and Austrian malacologists provides a historical baseline for faunistic and ecological surveys of aquatic Mollusca in this country (Hazay 1880, Clessin 1887-1890, Soós 1943, 1956). The current knowledge on the Hungarian freshwater malacofauna is summarized in some recent surveys and keys (FAlKner et al. 2001, Glöer 2002, 2019, Fehér et al. 2006, Welter-Schultes 2012). Despite this, a possibility to find a previously overlooked mollusc species in Hungary remains. During my work with the malacological collection of the Hungarian Natural History Museum in Budapest, a lymnaeid species Ladislavella occulta (Jackiewicz, 1959) has been identified as a new for the Hungarian fauna. Below I provide the data about this finding, with general considerations of taxonomy and distribution of this rare snail.

\section{MATERIAL AND METHODS}

I used malacological collections of some large zoological repositories of Europe, including Hungarian Natural History Museum (HNHM), Zoological Institute of the Russian Academy of Sciences (Saint-Petersburg; ZIN), Zoological Museum of the Moscow State University (Moscow; ZMMU), Gothenburg Natural History Museum (NHMG), and Berlin Museum of Natural History (ZMB). Also, I examined numerous lots of various Ladislavella species kept in the Laboratory of Macroecology and Biogeography of Invertebrates, St. Petersburg State University (LMBI). 

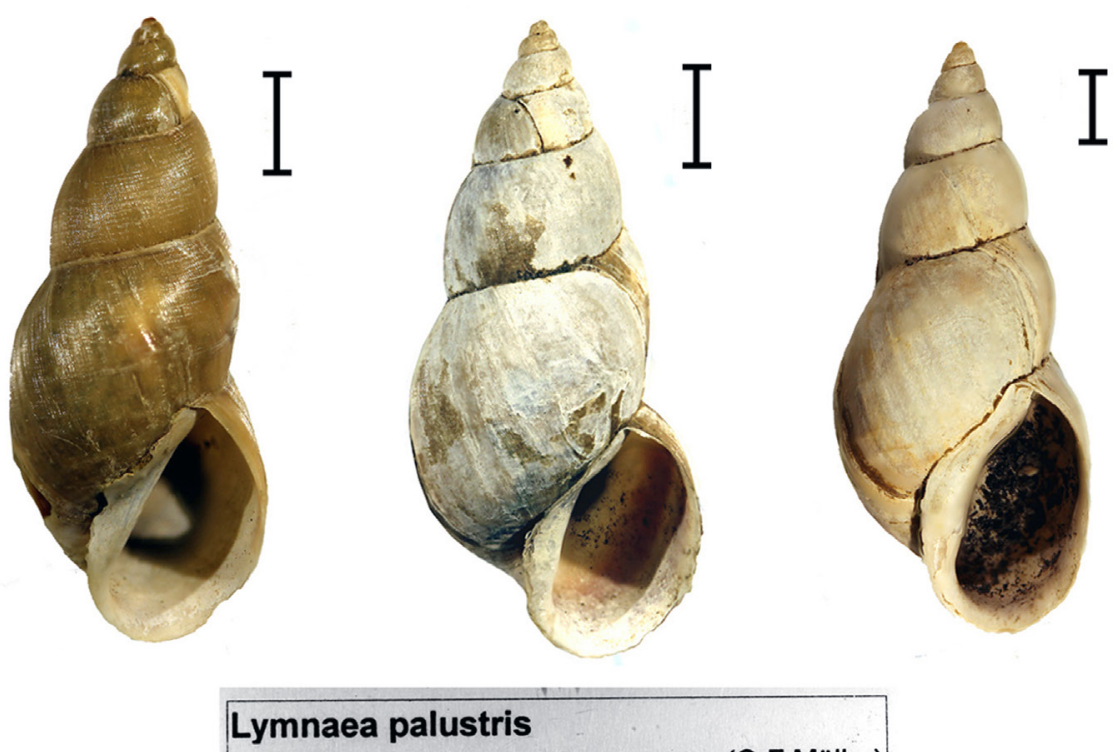

(O.F.Müller)

\begin{tabular}{|c|c|}
\hline \multicolumn{2}{|l|}{ H, Bátorliget } \\
\hline \multicolumn{2}{|c|}{ 1989.09.04. Leg.: Molnár A. } \\
\hline $72490 / 15$ & Hungarian Natural History Museum \\
\hline
\end{tabular}
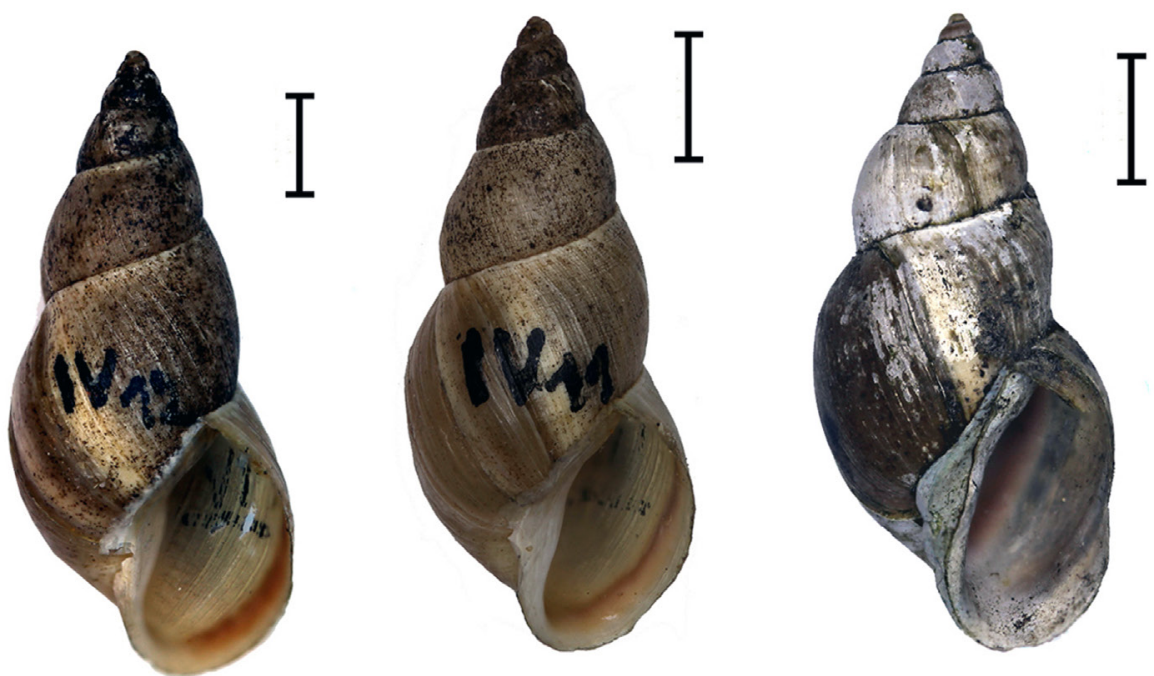

Fig. 1. Shells of Ladislavella occulta from Hungary and Poland. Upper row - Hungary, Bátorliget (HNHM), lower row - three paratypes of this species from Rawicz, Poland (ZIN). Scale bars: $2 \mathrm{~mm}$ 
The identification of L. occulta was made by using the original description of this species (JACKIEWICZ 1959) as well as by comparison of studied shells with the paratypes of Galba occulta kept in ZIN. Most samples examined during this study were represented by dried shells collected in the second half of the 19th - first half of the 20th century. Though it is thought that the lymnaeid shells do not represent a solid base for species identification, due to high level of their intra- and interspecific variation (HUBENDICK 1951, JACKIEwicz 1993), the discussed species represents an exception among the European lymnaeids. Namely, its shell bears a set of qualitative characters allowing reliable determination even when anatomical and/or molecular data are absent. The diagnostic characters of L. occulta are as follows: the cylindrical shape of the shell, flattened whorls, separated by a shallow suture, and the presence of a chalky-white columellar lip, which is thick and wide (JACKIEWICZ 1993, 1997, VINARSKI 2003).

\section{RESULTS}

In the malacological collection of HNHM, a sample of 15 empty shells, whose conchological characters correspond to both the type specimens (paratypes) and the original description of Ladislavella occulta, was found (Fig. 1). The label reads 'H[ungary], Bátorliget. 1989.09.04. leg. Molnár A." Most shells belonged to adult, full-grown individuals, with their shell height up to $13.5-14.0 \mathrm{~mm}$. All shells demonstrate the characteristic wide chalky-white columellar lip (see Fig. 1) that allows me to identify them as belonging to L. occulta. The exact habitat, or sampling site, of these snails is unknown. It may be hypothesized that the sample was collected in the Bátorliget Nature Reserve, in the northern edge of the Great Hungarian Plain, approximately $2 \mathrm{~km}$ west of the Hungarian-Romanian border. This protected area has a marshland area survived there since the Upper Pleistocene (SüMegr et al. 2003).

I was unable to find other samples of L. occulta during my work with an extensive collection of HNHM, which contains more than one thousand lymnaeid samples. Thus, Bátorliget remains the only locality of this species in Hungary known so far.

\section{DISCUSSION}

To the date, ten native species of the Lymnaeidae have been recorded from Hungary: Lymnaea stagnalis (L., 1758), Galba truncatula (O.F. Müller, 1774), Radix auricularia (L., 1758), R. ampla (Hartmann, 1821), R. balthica (L., 1758), R. peregra (O.F. Müller, 1774), R. lagotis (Schrank, 1803), Stagnicola palustris (O.F. Müller, 1774), S. corvus (Gmelin, 1791), and S. fuscus (Pfeiffer, 1821) (Soós 1956, Falkner et al. 2001, Glöer 2002, 2019, Fehér et al. 2006). No published records of L. occulta from the territory of Hungary are known.

The history of taxonomic and biogeographic studies of this species is remarkable and needs to be briefly presented here. After its original description 
(JACKIEWICZ 1959), this snail was reported from different regions of Central and Eastern Europe, including the former Czechoslovakia (HudEC \& BRABENEC 1966, Beran 2008), Western Ukraine (Stadnichenko 1968, 2004, Korniushin 1999), various parts of Poland (Berger 1961, Piechocki 1979, JACKiewicz 1998 2000), the former Yugoslavia (JACKiewicz 1997), East Germany (Zeissler 1999, GlöER 2002), and even from Sweden (Jackiewicz \& von Proschwitz 1991). The latter record was, however, based on erroneous identification, and L. occulta is actually absent from the Swedish malacofauna (T. von Proschwitz, pers. comm.).

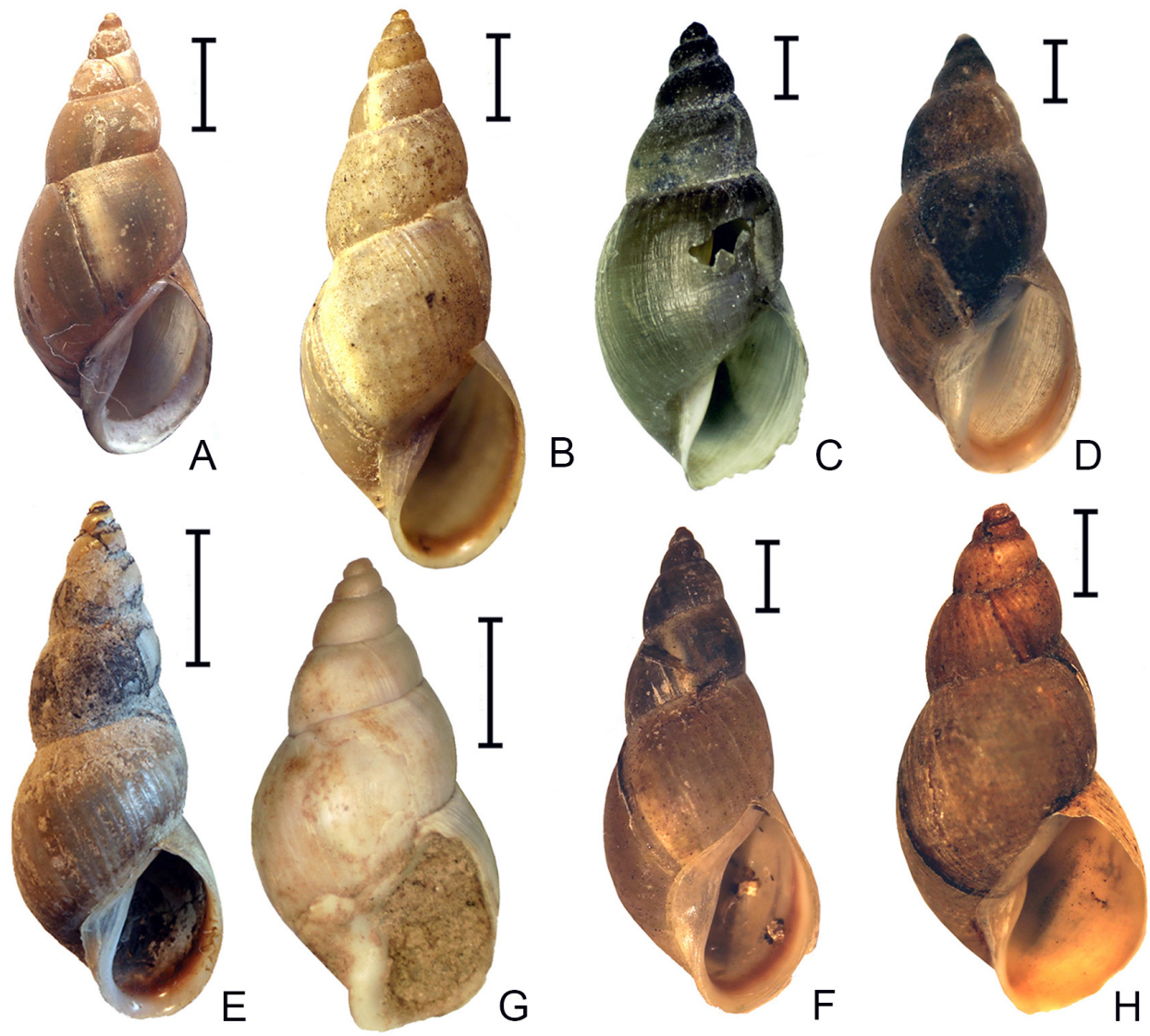

Fig. 2. Shells of L. occulta (A-G) and L. terebra $(\mathrm{H})$ from various countries of Central and Eastern Europe. A. Ukraine, Zhitomir Region, Dzerzhinsk (ZMB); B. Germany, Halle District, Salziger Lake (NMG); C. Ukraine, Transcarpathian Region, a pool in Khust District (LMBI); D. Russia, Moscow Region, Oka River basin, without exact locality (ZMMU); E. Russia, Republic of Mordovia, Alatyr' River near Obrochnoye station (ZIN); F. Russia, Kursk Region, Seym River near L'gov Town (ZIN); G. Ukraine, Poltava Region, Lubny District, Pleistocene deposits (ZIN); H. Russia, Barents Sea, Kolguev Island (ZMMU). Scale bars: $2 \mathrm{~mm}$ 
The species was mentioned in the European literature under different binomens: Galba occulta, Lymnaea occulta, Stagnicola occultus, and Catascopia occulta that reflects the taxonomists' changing views on the generic classification of the Lymnaeidae (Jackiewicz 1959, 1993, 1998, Meier-Brook \& Bargues 2002, VINARSKI 2012).

In my earlier paper (VINARSKI 2003), I brought the arguments that Galba occulta Jackiewicz, 1959 is a junior synonym of another lymnaeid taxon, Limnaea palustris var. terebra Westerlund, 1885, widely distributed in Siberia. JACKIEWICZ $(1992,2000)$ herself recorded this species from Siberia, under the name Lymnaea occulta. This opinion was based on the fact of virtual morphological identity between the paratypes of G. occulta and the Siberian representatives of $L$. terebra. The arguments were further developed in subsequent papers ( $\mathrm{VI}_{\mathrm{I}}-$ NARSKI \& GlÖER 2008, VinARski 2012) and accepted by some Polish malacologists (Piechocki \& WaWrzyniak-Wydrowska 2016).

In 2018, a genetic study showed that snails of the Polish populations of Ladislavella terebra are separated from the Siberian ones by a significant genetic distance, which justifies their species distinctness. The mean genetic distance between L. occulta and L. terebra constituted $12.6 \%$ for COI and $4.4 \%$ for ITS2 sequences (Pieńkowska \& Lesicki 2018).

Thus, the Code-compliant name for the East European species should be Ladislavella occulta (see GLÖER 2019). The eastern boundary of its range is still

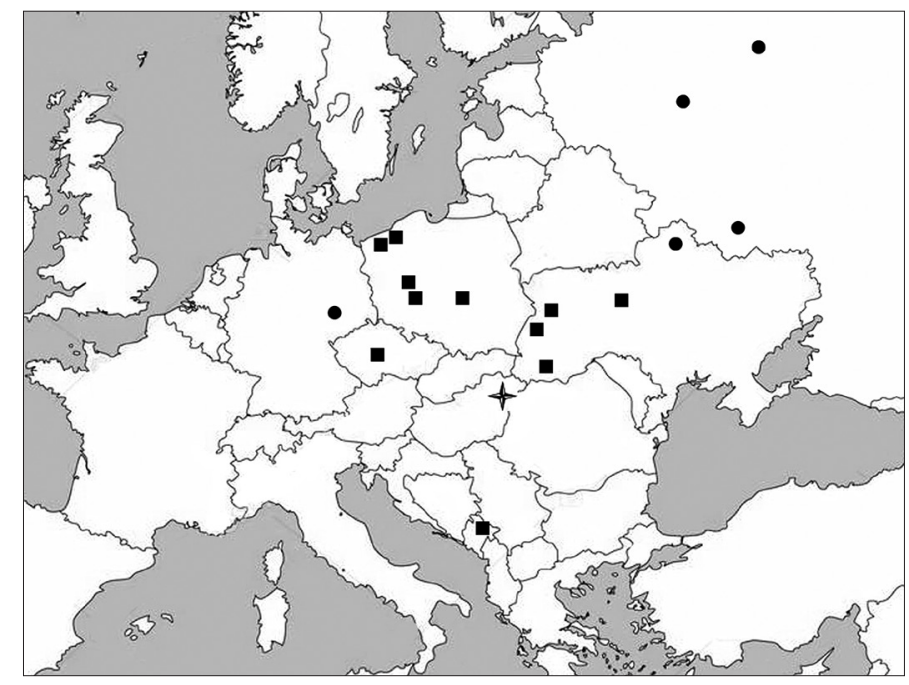

Fig. 3. A map of Europe showing known findings of L. occulta. The Pleistocene records are not shown, This map is based on data published in literature (JACKIEWICz 1998, 2000; BERAN 2008, Stadnichenko 2004, Anistratenko et al. 2018) and own data. Squares indicate findings identified by anatomical data; circles - findings based on empty shells. The location of Bátorliget is indicated by a star 
unclear, whereas the westernmost populations of L. terebra are known from the extreme northeast of Europe: the Pechora River basin and the Kolguev Island (Sмітн 1896, my unpublished data).

L. occulta is now represented in several countries of Europe (Fig. 3) but in all of them is rare and known from a few locations. It is true for the Czech Republic (Horsák et al. 2013), Ukraine (Korniushin 1999, Stadnichenko 2004 - as Lymnaea vulnerata; AnistratenKo et al. 2018 - as Ladislavella terebra), the former Yugoslavia (JACKIEWICZ 2000), and for Hungary (this study). During my work with museum collections, I was able to find other shells morphologically corresponding to L. occulta and, most probably, belonging to this species (Fig. 2). These shells were collected from Germany, Ukraine, and the European part of Russia (including the Quaternary deposits). Such a pattern of distribution (very sporadic) supports the hypothesis that L. occulta is a relic of the Quaternary glaciations of Europe, possibly originated from L. terebra. The latter snail is still very widespread in Siberia and inhabits different latitudes, including those situated north of the Arctic Circle (VINARSKI \& GlöER 2008, VinARSKi 2009, Andreyeva et al. 2010). It is not impossible that the extinct species, described by ANdreAe (1884) as Limnaeus (Limnophysa) palustris var. diluviana, is identical with L. occulta. The shells of this fossil lymnaeid, which was considered as a characteristic species of the Pleistocene malacofauna of Eastern Europe, including Hungary (Soós 1926), morphologically are very similar to those of L. occulta. The latter, thus, may be a direct descendant of $L$. diluviana, or even conspecific to it. Possibly, L. occulta represents a relict species of the glacial age in Hungary, which survived in this refugium.

The ecological preferences of L. occulta are as follows. According to BERAN (2008), it lives in temporary pools. Similarly, JACKIEWICZ $(1998,2000)$ describes this snail as an inhabitant of temporary water bodies of various types - "drying forest or sometimes meadow ditches, also in neglected drying nursery ponds, moreover in shallow streams and bogs. ... L. occulta is peculiar in its high resistance to the lack of water" (JACKIEwICz 1998: 60). In Ukraine, it has been recorded from astatic (temporary) water bodies like forest and meadow bogs (STADNICHENKo 2004).

A new malacofaunistic survey of the Bátorliget Nature Reserve marshland area is very desirable in order to determine the current status of L. occulta in this protected area. Though this snail was omitted in the European Red List of Non-marine Molluscs (CutTELod et al. 2011), it definitely deserves a protected status at the Pan-European scale. This species is ranked as 'critically endangered' in the Czech Republic (Beran 2008); in Germany, it is placed under ' $R$ ' (extremely rare) category (GLöER 2015). The main threat to L. occulta is habitat degradation (Honsák et al. 2013). On the other hand, this lymnaeid is known to transmit the liver fluke larvae (CZAPSKI 1965), which makes it a probable focus of epidemiological and veterinary research in Hungary and adjacent countries. 
Acknowledgements - My work with malacological collection of the Hungarian Natural History Museum was made possible by a grant from the Synthesys+ program (project No. HU-TAF 2697). I wish to express my gratitude to Dr. Zoltán Fehér (HNHM), who helped me during this work and discussed some points of this paper. Two anonymous reviewers are acknowledged for their comments on the manuscript. My studies of former SiberianEuropean faunistic connections during the Pleistocene are supported by the Russian Scientific Fund (grant No. 19-14-00066).

\section{REFERENCES}

Andreae, A. (1884): Der Diluvialsand von Hangenbieten im Unter-Elsass, seine geologischen und palaeontologischen Verhältnisse und Vergleich seiner Fauna mit der recenten Fauna des Elsass. - Abhandlungen zur geologischen Specialkarte von Elsass-Lothringen 4(2): 1-81.

Andreeva, S. I., Andreev, N. I. \& Vinarski, M. V. (2010): Key to freshwater gastropods of Western Siberia (Mollusca: Gastropoda). V. 1. Gastropoda: Pulmonata. Fasc. 1. Families Acroloxidae and Lymnaeidae. - The authors, Omsk, 200 pp. [in Russian]

Anistratenko, V. V., Vinarski, M. V., Anistratenko, O. Yu., Furyk, Yu. I. \& Degtyarenko, E. V. (2018): New data on pond snails (Mollusca: Gastropoda: Lymnaeidae) inhabiting the Ukrainian Transcarpathian: diversity, distribution and ecology. - Ecologica Montenegrina 18: 1-14. https://doi.org/10.37828/em.2018.18.1

Beran, L. (2008): A contribution to distribution of genus Stagnicola and Catascopia (Gastropoda: Lymnaeidae) in the Czech Republic. - Malacologica Bohemoslovaka 7: 70-73.

Berger, L. (1961): Mięczaki pogranicza Wielkopolski, Śląska i Jury Krakowsko-Wieluńskiej. Prace komisji biologicznej, wydzial matematiczno-przyrodniczy. Poznanskie Towarzystwo Przyjaciół Nauk, Poznań 25(1): 1-124.

Clessin, S. (1887-1890): Die Mollusken-Fauna Österreich-Ungarns und der Schweiz. - Bauer \& Raspe, Nürnberg, 858 pp.

Cuttelod, A., Seddon, M. \& Neubert, E. (2011): European Red List of Non-marine Molluscs. Publications Office of the European Union, Luxembourg, $98 \mathrm{pp}$.

CzApsKI, Z. (1965): Z badań nad biologią Galba occulta Jack., 1959 - nowego żywiciela pośredniego Fasciola hepatica L. - Wiadomości Parazytologiczne 11(Suppl. 1-2): 273-277.

FALKNer, G., BANK, R. A. \& von Proschwitz T. (2001): Check-list of the non-marine molluscan species-group taxa of the states of Northern, Atlantic and Central Europe (CLECOM I). - Heldia 4: 1-76.

Fehér, Z., Majoros, G. \& VArga, A. (2006): A scoring method for the assessment of rarity and conservation value of the Hungarian freshwater molluscs. - Heldia 6(3-4): $101-114$.

GLÖER, P. (2002): Die Süßwassergastropoden Nord- und Mitteleuropas: Bestimmungsschlüssel, Lebenweise, Verbreitung. - Die Tierwelt Deutschlands. Conchbooks, Hackenheim 73: 1-327.

GLöER, P. (2015): Süßwassermollusken. Ein Bestimmungsschlüssel für die Bundesrepublik Deutschland. 14. überarbeiteten Auflage. - Deutscher Jugendbund für Naturbeobachtung, Hamburg, $135 \mathrm{~S}$.

GlöER, P. (2019): The freshwater gastropods of the West-Palaearctis. Volume 1. Fresh-and brackish waters except spring and subterranean snails. Identification key, anatomy, ecology, distribution. - Published by the author, Hetlingen, 400 pp. 
Hazay, J. (1880): Die Molluskenfauna von Budapest. - Malakozoologische Blätter, Neue Folge 3: 1-69, 160-183.

Horsák, M., JuňičKová, L. \& Picka, J. (2013): Měkkýši České a Slovénské republiky. - Kabourek, Zlín, 264 pp.

Hubendick, B. (1951): Recent Lymnaeidae. Their variation, morphology, taxonomy, nomenclature and distribution. - Kunglike Svenska Vetenskapsakademiens Handlingar, series 4 3(1): 1-223.

Hudec, V. \& Brabenec, J. (1966): Neue Erkenntnisse über die Schnecken der Gesamtart Galba palustris (Müll.) aus der Tschechoslowakei. - Folia Parasitologica 13(2): 132-143.

JACKIEwicz, M. (1959): Badania nad zmiennością i stanowiskiem systematycznym Galba palustris O.F. Müll. - Prace komisji biologicznej, wydział matematyczno-przyrodniczy. Poznanskie Towarzystwo Przyjaciót Nauk 19(3): 1-86.

JAckiewicz, M. (1992): Lymnaea (Stagnicola) occulta (Jackiewicz, 1959) (Gastropoda: Pulmonata) in Sibirien. - Mitteilungen der Deutschen Malakozoologischen Gesellschaft 49: 13-16.

Jackiewicz, M. (1993): Phylogeny and relationships within the European species of the family Lymnaeidae. - Folia Malacologica 5: 61-95. https://doi.org/10.12657/folmal.005.003

Jackiewicz, M. (1997): New European locality of Lymnaea (Stagnicola) occulta (Jaczkewicz, 1959) (Gastropoda, Basommatophora, Lymnaeidae). - Malakologische Abhandlungen / Museum für Tierkunde Dresden 18(2): 255-259.

Jackiewicz, M. (1998): European species of the family Lymnaeidae (Gastropoda, Pulmonata, Basommatophora). - Genus 9(1): 1-93.

Jackiewicz, M. (2000): Błotniarki Europy (Gastropoda, Pulmonata, Lymnaeidae). - Kontekst, $116 \mathrm{pp}$.

Jackiewicz, M., von Proschwitz, T. (1991): Lymnaea (Stagnicola) occulta (Jack.), Lymnaea (Lymnaea) vulnerata Küst. und Lymnaea (Lymnaea) corvus (Gmel.) - drei für Schweden neue Schlammschneckenarten (Gastropoda, Basommatophora: Lymnaeidae). - Malakologische Abhandlungen / Museum für Tierkunde Dresden 15: 125-132.

Korniushin, A. V. (1999): New records of Lymnaea (Stagnicola) species in the West Ukraine (Gastropoda: Basommatophora: Lymnaeidae). - Malakologische Abhandlungen / Museum für Tierkunde Dresden 19: 281-286.

Meier-Brook, C. \& Bargues, M. D. (2002): Catascopia, a new genus for three Nearctic and one Palaearctic stagnicoline species (Gastropoda: Lymnaeidae). - Folia Malacologica 10(2): 83-84. https://doi.org/10.12657/folmal.010.008

Piechоскі, A. (1979): Mięczaki (Mollusca). Ślimaki (Gastropoda). - Fauna slodkowodna Polski 7: 1-188. Panstwowe Wydawnictwo Naukowe.

Piechocki, A. \& Wawrzyniak-Wydrowska, B. (2016): Guide to freshwater and marine Mollusca of Poland. - Bogucki Wydawnictwo Naukowe, Poznań, 280 pp.

Pieńkowska, J. R. \& Lesicki, A. (2018): A note on the status of Galba occulta Jackiewicz, 1959 (Gastropoda: Hygrophila: Lymnaeidae). - Folia Malacologica 26(4): 231-247. https://doi.org/10.12657/folmal.026.029

Sмiтн, E. A. (1896): On some freshwater shells from the island of Kolguev. - Proceedings of the Malacological Society of London 2: 104. https://doi.org/10.1093/oxfordjournals.mollus.a064648

Soós, L. (1926): The past of the Hungarian mollusk fauna. - Annales Musei historico-naturalis hungarici 24: 392-421. [in Hungarian]

Soós, L. (1943): Kárpátmedence Molluscafaunája. - Magyar Tudományos Akadémia, Budapest, viii+478 pp. 
Soós, L. (1956): Csigák I. Gastropoda I. - Faunae Hungariae. Vol. 19(2), Akadémiai Kiadó, Budapest, 80 pp. [in Hungarian]

Stadnichenko, A. P. (1968): Galba occulta Jackiewicz, 1959 (Gastropoda, Pulmonata) - new species for the USSR fauna. - Zoologicheskiy Zhurnal 47(6): 942-944. [in Russian]

Stadnichenko, A. P. (2004): Pond snails and limpet snails (Lymnaeidae, Acroloxidae) of Ukraine. - Tsentr uchebnoy literatury, Kiev, 328 pp. [in Russian]

Sümegi, P., Daniel, P., Kovács-Pálffy, P., Juhász, I., Deli, T. \& SzÁntó, Zs. (2003): Geohistory of Bátorliget-marsh. - Tájökológiai Lapok 1(1): 97-114. [in Hungarian]

VINARSKI, M. V. (2003): The systematic position of Lymnaea vulnerata (Küster, 1862) and L. occulta (Jackiewicz, 1959) (Mollusca: Gastropoda: Lymnaeidae). - Zoosystematica Rossica 12(1): 23-27.

VINARSKI, M. V. (2009): Geographical variability in the male genitalia in two stagnicoline species (Gastropoda: Pulmonata: Lymnaeidae). - Mollusca (Dresden) 27(2): 157-166.

VinARski, M. V. (2012): The lymnaeid genus Catascopia Meier-Brook et Bargues, 2002 (Mollusca: Gastropoda: Lymnaeidae), its synonymy and species composition. - Invertebrate Zoology 9(2): 91-104. https://doi.org/10.15298/invertzool.09.2.02

VinARsKI, M. V. \& GLÖER, P. (2008): Taxonomical notes on Euro-Siberian freshwater molluscs. 3. Galba occulta Jackiewicz, 1959 is a junior synonym of Limnaea palustris var. terebra Westerlund, 1885. - Mollusca (Dresden) 26(2): 175-185.

Welter-Schultes, F. (2012): European non-marine molluscs: a guide for species identification. Planet Poster Editions, Göttingen, 674 pp.

Zeissler, H. (1999): Molluskenfauna von Nordwestsachsen. - Veröffentlichungen Naturkundemuseum Leipzig 17: 1-95.

Received June 12, 2020, accepted August 17, 2020, published November 13, 2020 


\title{
The distribution of Hungarian molluscs
}

\section{The catalogue of the Mollusca Collection of the Hungarian Natural History Museum}

\author{
Z. Fehér and A. Gubányi
}

Authors aimed to continue the traditions of Hungarian faunal mapping set by Pintér and co-workers in 1979, and to create a computer programme and a database, that are able to collect and manage data both from the literature and collections and able to create distribution maps. Due to this "living" data system, where the integration of new data is permanently done and the errors are continuously corrected, the results are published in electronic format in English and Hungarian. The CD contains the catalogue in pdf format (the reader programme Adobe Acrobat Reader 4.0 also present). As the first step, this CD contains the checklist of the Hungarian molluscs and their distribution data based on the Mollusca Collection of the Hungarian Natural History Museum. Distribution of the 220 gastropod and 24 bivalve species in the collection are illustrated in $10 \times 10 \mathrm{~km}$ UTM grid maps, and all of their sampling sites are listed by UTM grids.

The checklist follows the nomenclature of the CLECOM (Checklist of the European Continental Mollusca) project. With all those speciess that are known under a different synonym name in Hungary, or occur in Hungary but not mentioned in the CLECOM list, or are missing from the HNHM collection, or that are incorrectly indicated in Hungary, or their taxonomic position is judged by a competent Hungarian malacologist in another way then given in CLECOM, authors deal with in the Appendix. A glossary of the frequently used common names and geographical terms helps the use of the locality list. This issue will hopefully be followed by others containing literature data and data of other Hungarian mollusc collections, and the series will become a useful tool for malacologists dealing with zoogeography, ecology and nature conservation.

Published in 2001. 466 pages on CD disk. Price: 30 euro plus p. and p.

ISBN 9637093702

Orders should be sent to

The Library, Hungarian Natural History Museum

H-1088 Budapest, Baross u. 13, Hungary

Fax: (36-1) 3171669 